\title{
ICT from Below: \\ ELISA Program and the Innovation of Local Government in Italy
}

\author{
Alessio Conti ${ }^{1} \&$ Giovanni Vetritto ${ }^{2}$ \\ ${ }^{1}$ Ict and Public Governance Advisor for Local Authorities, Roma, Italy \\ ${ }^{2}$ Director General, Presidenza del consiglio dei ministri, Roma, Italy \\ Correspondence: Giovanni Vetritto, Director general, Presidenza del consiglio dei ministri, Roma, Italy.
}

Received: February 7, 2019

doi:10.11114/ijsss.v7i3.4203
Accepted: March 29, $2019 \quad$ Available online: April 9, 2019

URL: https://doi.org/10.11114/ijsss.v7i3.4203

\begin{abstract}
In the last two decades, there has been a shift in the fundamental paradigm of Public Administration, from New Public Management, characterized by a managerial, microeconomic and sectorial approach, to Multilevel Public Governance, characterized by an integrated, strategic and holistic approach. The current Multilevel Public Governance paradigm is particularly useful to study and to approach to the Italian local government sector, due to its extreme fragmentation that needs cooperation to overcome its limits. It is in this theoretical framework that we present the ELISA program and its efforts in modernizing the local administration with ICT... from below.
\end{abstract}

ELISA program (Enti Locali - Innovazione di SistemA, Local Government - System Innovation) is a national government project for the innovation in the Public Administration, guided by the Department for Regional and Local Affairs. The project promotes innovative instruments to develop software and technological public platform in three different main fields: taxation and cadastre; info-mobility; quality of services. The ultimate goal is to increase the efficiency of the administrative structure and provide better and technologically advanced solutions to respond to the needs of the citizens.

Considering the success of the ELISA program, the Department for Regional and Local Affairs, in cooperation with Politecnico di Milano and Invitalia s.p.a., activates the eGovernment Laboratory with the aim in guaranteeing the replicability and the uniform dissemination of the best solutions all along the country. One of its action lines is to develop and implement the Innovation Communities raised in connection with the best practises of the ELISA program. For this purpose, it encourages sustainable and innovative management models, which are able to spread significant benefits by passing on administrative skills and knowledge to other Public Administrations and, furthermore, promoting the implementation mechanism and the deployment of the experiences.

For that to happen, system-oriented measures are needed in order to redefine the relationship between the Local Authorities and the Central Administration: the first ones have the task to identifying both problems and needs of their territories and design proper solutions accordingly; the second one has to guarantee constant and consistent funds, coordinate the actions and oversee the whole process. One example of system-oriented measure is ItaliAE project, a complex and technological program, financed by European structural funds and born to follow the implementation of the local authority reform provided for by the law n. 56/2014 and to support the transformation of the Italian administrative geography and to improving its efficiency.

Keywords: governance, ELISA program, innovation, innovation communities, ItaliAE, eGovernment, new public management, multilevel public governance, public administration

\section{The Central Administration and the Local Authorities in the Innovation Process}

\subsection{From New Public Management (NPM) to Multilevel Public Governance (MPG) in the Innovation and ICT Era}

For a better understanding of the importance of the ELISA program in the field of the developing of Italian Public Administration, it is crucial to be aware of the evolution of the fundamental paradigm of the modernization, in general terms, of all administrative systems in the world (Osborne \& Gaebler, 1992; OECD, 2005).

During the period that goes from the late 1980s to the early 1990s, the address of comprehensive administrative reforms worldwide was the one of New Public Management (Pollitt \& Bouckaert, 2004). In recent years, due to the general 
disaffection with that approach, especially in the countries that experimented it in a deeper and pervasive way (like New Zealand and Great Britain), a new paradigm rose, based on totally different socioeconomic and organizational principles (Vetritto, 2010).

NPM inspired reforms that were characterized by a sort of economic and managerial preconception that soon revealed itself to be too simplistic. In the context of a strong revival of the free market neoclassical approach, as a reaction against the XX century Keynesian revolution, every Constructivist public policy (in the sense adopted by Hayek in his works (Hayek, 1982) has been devalued and the ultimate goals of any public activity were reconducted to the logic of microeconomic efficiency. The only admitted public value to be produced, from this point of view, was the sum of separate single microeconomic efficient services. As a consequence, a number of quasi-markets for single administrative services or products were enabled, and each Public Administration had a performance relation with its governmental directive body, fixing mid and long term service level agreements that were the condition for activity, level of services and remunerations of public managers.

As a matter of fact, NPM was not, as it was intended in Italy, the mere adoption of managerial technicalities in the skills matrix of public managers; it was a comprehensive organizational and institutional rebuilding that gave start to the so-called process of agencification (Christensen \& Laegreid, 2006; Verhoest, 2017): the outsourcing of public single-product bodies with business goals and models.

In each agency, tied to the ministerial sector by performance contracts, market logics and technicalities were practiced, with the aim of reducing costs and maximizing the efficiency in the production of any administrative service or product. Management and salaries were fixed upon a medium or long period, without any connection among different agencies.

The most ambitious reform process in this sense was realized in New Zealand during the ' 90 s, and since the early years of the new century saw dissatisfaction and changes of address. Two main problems rose from the coherent adoption of NPM and agencification model. On the one hand, the fixing of medium and long term microeconomic performance goals in separate agencies precluded shot term corrections and adjustments; and, above all, it became impossible to organize wider, integrated and horizontal policies with more ambitious goals. On the other hand, the "business oriented" approach came to predominate in the electoral circuit (citizens - parliaments - governs) in the pursuit of more complex goals, other than the saving of resources, for example in the changing of socioeconomic conditions considered unequal or in any sense not approved by the majority of the electoral body (Rennie, 2005).

The most important criticism to the NPM model, anyway, moved on a different level: it implied the inadequacy of the "quasi-market" logic on a conceptual and cognitive basis.

During the previous century, the most incisive criticism to the social welfare model was conducted on the same level: the impossibility for a central planner to have all the necessary information about preferences and situations of the citizens was the key assumption of thinkers like Ludwig von Mises (1933) and Friedrich August von Hayek (1982), that the Keynesian and democratic culture were unable to dismantle. But on the same epistemological level the new model turned out to be inadequate too.

NPM was based on the wrong assumption of considering means and goals of the administrative (and political) action as known. That was barely possible in the small number of years that saw the prevalence of the neoclassic revenge, of the minimal State and of the self-regulation of rationale social actors disputed. Until then the simple contractual or quasi-contractual logic was considered sufficient to solve the main collective problems and challenges.

When this prevalence started to unravel, long before the major crisis of 2008, preferences and orientations of the majority of citizens started moving to the request of more demanding and integrated policies, which the contractual and business-oriented model couldn't afford to give (Guy Peters \& Pierre, 1998).

A very simplified decision matrix, dividing choice conditions of public policies in four quadrants, taking into account certain or uncertain means and goals, NPM assumed working mainly in the first box, while any sophisticated theory can demonstrate that Public Administration usually works in the fourth box (Table 1).

Table 1. the decision matrix

\begin{tabular}{|c|c|}
\hline CERTAIN MEAN & CERTAIN MEANS \\
CERTAIN GOALS & UNCERTAIN GOALS \\
\hline UNCERTAIN MEANS & UNCERTAIN MEANS \\
CERTAIN GOALS & UNCERTAIN GOALS \\
\hline
\end{tabular}

For a number of years, the world blindly believed only in the return to the logic of the invisible hand and of the pull of efficiency. The technological revolution that started at the end of the last century gave to the economic actors more and 
more room for efficiency gains and organizational rationalizations, leading to the overcoming of Fordism. In more recent years, the same technologies have given the economic actors a new awareness about the chance to reconsider transactional, organizational and operational choices using the network model, the "coopetition" dynamics, and more interconnected relations between private and public sector: the referring is to the concept of milieu innovateur theorized in the nineties by Manuel Castells (2010). On a territorial level, there has been a rediscovery (Hidalgo, Klinger, Barabàsi \& Hausmann, 2007) of the Hirschmanian economic theory of agglomerations (Hirschman, 1958, 1963, 1967), highlighting the basic value of social capital and distributed knowledge (Dahrendorf, 1959, 2003).

This new address led to more complex and integrated urban and territorial development policies, based on the coalition of a wide range of public and private actors, in the shape of the well-known strategic planning practice (Perulli, 2004). This new deal of the programming methods rejected the traditional top- down authoritarian logic and gave birth to a new logic of programming, by means of reticular bottom up dynamics, which are no longer authoritarian, complex transactional methods, adherent to the economic paradigm of place-based economics (Barca, 2011). It is a new way of coordinating a large volume of knowledge, information and preferences of the more relevant actors of any public choice.

The revenge of the market versus the State left progressively room to a new awareness about the inextricable connection of the public and private sectors, especially by means of the new "connective" and "cooperative" ICT technologies. What once, in the words of the most important Italian political scientist of the last century, was the "great dichotomy" between "public" and "private" became a syncretism of both (Bobbio, 1974).

A number of cultural developments stemmed from this change of attitude in policy making: from the new success of the theory of capitalism of Karl Polanyi (2013), to the Nobel prize of a thinker like Elinor Ostrom (2007), who dedicated her entire research life tearing down the enemy's myths of the Leviathan State and of the self-regulating invisible hand market.

Even on the macro institutional level we see developments made possible by the overcoming of the traditional realities of time and space. For example, the traditional federalism (Marks, 1993) has become operatively obsolete and conceptually useless, in front of the different logic of dialectics, subsidiarity, and cooperation among different levels of government. In the new technological context, it is possible to help negotiate and divide tasks of vertically integrated territorial policies (OECD, 2017).

It is the new paradigm of Multilevel Public Governance, which inspires and models the rethinking of all forms of thinking and acting on public functions and services. MPG does not entirely cancel the previous NPM; the capital of technicalities, concepts, efficiency logics partly survive in the new paradigm; but the core is no longer about efficiency and savings but on efficacy and mutual gains. It is a qualitative change that smooths the asperities of the market logic to enable a new cooperative attitude for all social actors in policy design. It is evident how much this paradigm depends on new technologies, on their capacity to help us to collect, organize, use knowledge, information, preferences, data. Ten years ago important scholars already declared the NPM overcome (Dunleavy, Margetts, Bastow \& Tinkler, 2006); the reason for that is the more useful and elastic methodology offered by the MPG in shaping and conducting public policies in the era of new digital means; an era characterized exactly by being digital.

\subsection{The Italian Public Administration and the Innovation Challenge}

The role of technology in the Public Administration is the main topic in the innovation process debate the Public Sector has been undergoing. This is indeed an inexorable and necessary process if we want to face the future challenges. The use of technological solutions makes the interaction with the public easier, facing their needs in a better way, defining a management platform for the local process and at the same time enabling the comparison between products and services provided by the various sectors of the Public Administration; and also evaluate the performance throughout accurate markers.

The introduction of Innovation technologies within the Public Administration cannot be seen just as a simple addendum to existing activities, as an "extra" to something already there or as a new kind of service made available to citizens. Most of the time the old products or/and service is not replaced by the new one, they are just left there to co-exist side by side. Sometimes it is up to the single office/administration to decide what to do with the new technology. From a practical point of view, setting up an office and filling it with IT technicians it's not the right way to deal with the innovation technology, or state its existence: we don't need to create a cluster which is separated from the other offices where working people are totally detached from the administrative life of the Public Administration. There is no good in just refreshing the room, placing lots of personal computers and change the label on the door if that would just be a cluster isolated from the other offices. Doing so we will just put a barrier between two different worlds, like people speaking different languages and unable to communicate, the computer technicians on one side and the rest of the Public Administration on the other side.

In this context, it would be hard to strengthen a good job able to produce more and better services for the citizens and also 
transferring and sharing information, experience and competences among different Public Administration sectors will be precluded. It is not relevant for a single Public Administration evaluate the permeability level among the public employees, the knowhow, or even estimate the competences of each employee, but it is important to focus on the level of diffusion of technology in the Public Administration, passing on and transferring the competences, especially the digital ones, which are the hardest to take root.

The main reason for this is because innovation has been seen as an extra service given to the citizen or a process in which only the single employee involved is interested and it is up to him carry it out. Misrepresentation of this acting is evident everywhere and reflects on the services provided. There are many examples of this, one it is the cadastre which has not been digitalized yet in most of the Italian municipalities and the majority of the employees do not know how to proceed (it is not uncommon the case that just one of them knows how to do the job and once he retires the information goes with him). Other examples are the Database: there is no Network connection among the different Public Administration so that the citizens are obliged to go back and forth among different public offices in order to provide information the Public Administration already has. This happens everywhere, at different levels, Local Governments and Central Administration as well, and they represent inefficiency, wastefulness examples causing disruption, delays, malfunction and inconveniences for the citizens. Politicians and Public Administration should wonder what they are doing to avoid this situation facing it with new eyes.

\subsection{The ICT as a Key Factor in the Public Administration Organizational Process}

Since that is the case, we have to be willing to shift perspective and start analysing Innovation as an intrinsic phenomenon of the company organisation, as an essential element in the Public Administration organizational process, upon which all its activities must be set up and organised and all its services provided. The Innovation technology should be all-embracing, as if the Administration is part of it, dipped in it, should be assimilates and understood by both the employees and the customers. Only when they have understood the advantages it will constitute that critical mass able to foster and sustain the changes under way in order to make it lasting and free from not going back. Moreover, the implementation of technology in the P.A. cannot be enclosed in a single service or declined as the target of a manager who has been asked to dematerialise a specific procedure or even replace and/or complement the "old" URP (Public Relations Office) with a virtual help desk. Such examples are just simple revisions to existing procedures which are just going to affect a single office either as a training or refresher course given to a single employee. Such as this they have no relevance as they do not give any contribution to the paradigm shift nor to a change of the business methods or the picture that citizens have of the Public Administration.

In order to do that we have to redefine the concept of innovation technology which can't be seen as a goal or just one of the Public Administration objectives. Innovation technology should be the enabling factor for a functioning Public Administration and the achievement of its mission. A prerequisite which can really change the way in which people think and their approach to Public Administration problems. This goes with computerization and sharing database and experiences, ensuring better standards in efficiency, economy and effectiveness, providing better products and services to the citizens and take a great leap forward in the countrywide system. We have to go over the actual condition, where in the majority of the Public Administration, the innovation process is still fragmented or relegated to small sectors and often lacks of substantial and sustainable investments in human resources. Bidding on human resources does not mean just organizing training and refreshing courses but there should be a permanent training in order not only to create the necessary expertise but to aim for the information-sharing and exchange of experience. If we are able to achieve this goal then the Public Administration will be able to provide quality services to its citizens and thoroughly fulfil its institutional mission.

\subsection{The Actors in the Field, a New Alliance for the Innovation}

The paradigm shift, which will enable technology and innovation to be the enabling factors in the organisational process, can take place only if there is a real change in the relationship between Central Administration and Local Authorities, a redefinition of their roles and functions, with a political leadership able to give a proper direction to our country and its Public Administration. But instead, nowadays, almost everywhere, there is a deep dualism between the Central Administration, which represent the very heart of the Public Administration, and the Local Authorities which are its direct branches, have to provide services to the citizens and at the same time have to implement innovative solutions: at the moment these two worlds speak different languages and we must create the right conditions to make them speak the same language again. It's a lengthy process, although, which politicians and national government institutions have the duty to start following, looking forward and establishing a strategic alliance in order to ensure the country a Public Administration able to create the conditions for a bottom-up development and growth, working in an integrated way within a strategy based on innovation as an enabling factor giving the country a genuine boost.

Our institutional system is really a complex one, with and more than 100 Provinces and 8,000 municipalities, half of 
which under 3,000 inhabitants, and about 6,000 over 8,000 under 5,000 inhabitants: such a fragmented system can hardly be efficient in a digital era. Technologies, in this situation, can offer a solution as they help mending this fragmented structure, facilitating and promoting a better cooperation in the Public Administration, being a very powerful driver of organizational and operational modernization (Vetritto, 2016). This will allow the creation of a critical mass which will change the decisional process and will be able to provide fast and better services to the citizens, thus being impossible in an analogic Public Administration.

The players involved have specific tasks which will be described in the following chapters. The Central Administration must identify and communicate the reference values, the long erm goals on which the Government action is based. It has to provide the necessary support so that the innovation processes could take place. This requires a clear vision ( $\$ 1.4 .1 .1)$ and deployment policies able to create a competitive system with clear regulations, a fast justice and a new competitive infrastructure where innovation processes can start and spread (§ 1.4.1.2); it has to guarantee consistent and constant funding, linked to the real needs of the territories ( $\S 1.4 .1 .3)$. Lastly, Central Administration has to create the right conditions so that the local good practise can spread and develop throughout the country and/or been adopted by other Public Administrations ( $§$ 1.4.1.4). This means that Local Authorities can generate innovation, becoming incubator centres, creating synergies and positivity which have important impact on the national economy and the services offered to citizens $(\S 1.4 .2)$.

\subsubsection{The Rule and the Functions of the Central Administration}

\subsubsection{A Clear Vision to Guide the Innovative Action and a Coherent Policy Strategy to Reach the Long-Term Objectives}

Public administration has to develop and then share a vision within which - thus being the complexity of the challenge before defining tasks and functions, create the perfect conditions so that politics, with its guidelines, and the administrative bureaucracy, which has to execute them, can co-exist and work side by side. It is a political responsibility to give directions, decide where to invest and which are the right and necessary reforms to carry out. A policy with no vision can just run a day-to-day administration and this can't be the case in a country which is nowadays trying to modernise its administration.

The more the political party loses its legitimacy, security and power the less it can make skilful and strategic choices in the long-term; implementation and modernization are quite difficult to achieve when there is no credibility and a feeble strategy. A weak policy is breathless, hungry for quick consent, always thinking about next imminent elections; this low-profile policy can't be the promoter of the innovation process. On the other side it is important to have and mould a bureaucracy which is not anchored to its own privileges and interests but it is willing to get involved and take its chances, so as to be the driving force of the innovation process. The innovation process is a challenge to all of us, it requires a change, a shift, an evolution from where we started, it carries with it a new know how and leads us to take decisions and make choices we never did before.

Public management must assume responsibility, be motivated and involved in the innovation process, being it the trainer, the one getting the ball rolling through public officers and civil servants. Do not disregard this because civil servants' feeling of belonging and motivation make the difference as they are the ones dealing directly with the citizens by giving information and public services. The positive or negative judgement given by the citizens on public governance often depends on how the civil servant interact with them. Even the most visionary, far-sighted politician will see his ideas founder if he does not have a brave management. At the same time a brave and competent management wouldn't go too far with a politician out of clear ideas as what to do and where to go.

Once the vision is clear new measures are needed in order to fulfil the task. Basically, the Central Administration has to define clearly the concrete actions to be followed in order to let the innovation process spread in a breeding ground. For that we need a policy strategy. We need a medium-long-term multi-sectorial dimension actions able to permeate even the deepest layers of society. The mission is change the old wheels and totally redefine the Public Administration machine. Civil servants' mind-set, of course, have to be changed, too, by creating a stimulating climate able to encourage and promote the professional growth, rewarding everyone's efforts when due but moving forward the new with the utmost rigour without looking back to the past. If the strategy is deeply rooted and inspired by a "vision", it will be successful and will give us back a transformed and efficient Public Administration which the citizens will feel as a resource, closer to their needs and able to fulfil its institutional mission.

\subsubsection{A Competitive System to Allow to the Experiences to Bed Down and Develop}

In order to underpin the implementation of these actions and the deployment of strategies, it is necessary to regain competitiveness, especially where it is lacking. According to the Global Competitiveness Report 2017-2018 (World Economic Forum, 2017), "Italy ( $43^{\text {rd }}$ out of the 137 countries) improves one place in the rankings slightly increasing its score, notably through improved goods market efficiency (up seven places to 60th) and higher education and training (up 
two to $\left.41^{\text {st }}\right)$. Its longstanding competitiveness advantages include health and primary education $\left(25^{\text {th }}\right)$, large market size $\left(12^{\text {th }}\right)$, infrastructure $\left(27^{\text {th }}\right)$, and business sophistication $\left(25^{\text {th }}\right)$. Despite recent reforms, labour markets $\left(116^{\text {th }}\right)$ and financial markets $\left(126^{\text {th }}\right)$ remain weak points". But a more careful look will reveal another weak point also in the institutional sector $\left(95^{\text {th }}\right)$ which measures the way in which public government take care of investors and, if we break down this sector, we will note that the values of some items are particularly negative.

The analysis shows that there too many boundaries and limits to private initiative, this being a consequence of Government regulatory activity $\left(134^{\text {th }}\right)$. Italy, over the past few years, has not been considered as a popular destination for investors, the cause of it being a very confuse, flawed and contradictory regulatory framework which led us to deal with a paradoxical situation fuelled over the years. On the one hand, we have a set of rules and regulations layered over the years, in particular in specific fields where Italy is an unicum among civil law countries; on the other hand, we lack ad hoc rules and laws for the benefit of the innovative realities where we often have to apply a legislation framework tailored to the traditional firms and not to their needs. Not having a clear vision and iter to follow, investors and businessmen feel themselves frustrated and powerless with respect to Public Administration and, consequentially, they are not be able to establish good relations with it. The responsibility is to be found in the lack of communication and cooperation among the various Public Administrations, obliging the citizens to go back and forth in order to provide documentation the Public Administration already has.

Moreover, the Report, with regard to our legal system, shows a deep inefficiency due to our inability to solve legal disputes between private parties $\left(134^{\text {th }}\right)$. It also underlines the difficulty that both business man and company have to face in the courts when a litigation arises as a respond to a government action or because the law or the regulation are ambiguous and their application is not clear $\left(128^{\text {th }}\right)$.

To be fully conscious of that, just think about law-making conflicts when central government and regions share the same competences or think about the necessity, sometimes, to produce interpretative legal acts because the law it's not clear. Another example is given by the never-ending disputes, like those started in 1960 regarding the expropriation of land in order to realize the infrastructures for the Rome Olympics and still pending today. In the end, you can also see what happens at the institutional call for tenders where the losers frequently file an appeal that can lead to postpone the realization of a public work.

Also, the Report shows us the lower position Italy occupies in other sectors such as: favouritism in decisions of government officials $\left(118^{\text {th }}\right)$; public trust in politicians $\left(122^{\text {nd }}\right)$; the total transparency of government policy-making $\left(126^{\text {th }}\right)$; efficiency of government spending $\left(126^{\text {th }}\right)$. All these data confirm that, as shown in the Report, among the 13 critical factors which frustrate doing business in Italy, the first position is occupied by the inefficiency of the government bureaucracy (17.6\%): from the second to the fifth position of this rank of the most problematic factor for doing business there are the level of tax rates $(17.3 \%)$, the restrictive labor regulation (11\%), the tax regulation $(10.5 \%)$ and the access to financing $(9.6 \%)$.

In order to gain point in competitiveness Italy has to reduce the digital divide and deploy policies able to spread the digital culture all over the country. To date, the situation, in this field, is far from being rosy, as pointed out by the Digital Economy and Society Index 2018 (European Commission, 2018). The DESI is a composite index that summarises relevant indicators on Europe's digital performance and tracks the evolution of EU member states in digital competitiveness. It's structured around five chapters: connectivity (it measures the deployment of broadband infrastructure and its quality); human capital/digital skills (it measures the skills needed to take advantage of the possibilities offered by digital); use of internet services by citizens (it accounts for a variety of online activities, such as the consumption of online content - videos, music, games, etc. - video calls as well as online shopping and banking); integration of digital technology by businesses (it measures the digitisation of businesses and e-commerce); digital public services (it measures the digitisation of public services, focusing on eGovernment and eHealth). The quantitative evidence from DESI along with country-specific policy insights, form the Europe's Digital Progress Report (European Commission, 2017). The EDPR allows EC to keep track of the progress made in terms of digitalisation by each Member State and providing an important feedback loop for policy-making at EU level.

According to this index, Italy is third-to-last and with an overall index score of 44,3 (41.4 in 2017) it ranks $25^{\text {th }}$ out of the 28 EU countries. The report underlines that "integration of digital technologies and digital public services are the main drivers of digital progress in Italy. Another positive aspect is its performance on next generation access (NGA) coverage, which is much improved (from 23rd in 2016 up to 13th in 2017). As in previous years, the main challenge is still the low level of digital skills, for which the Italian government has taken some (but not enough) steps." So, even if something is moving in the right direction, this is not enough and there is still a lot to be done if we want to make up the gap accumulated towards Europe. But it is not all bad, there are some positive elements.

Connectivity is a good example. In the last two years, Italy has made significant progress especially when talking about 
fibre-optic connections (from $41 \%$ up to $87 \%$ ) but, even if the costs of fixed broadband decrease and Italy has the same broadband price index of the EU average (87), mobile broadband take-up (77\% up to $86 \%$ ) is still under the EU average (90\%) and, fixed broadband take-up increases slightly (from 53\% up to 57\%) but it's quite far from the EU28 average (75\%), relegating thus Italy to last place among the EU countries. As for human capital, with respect to the last year, internet users have slightly increased (from $67 \%$ to $69 \%$ compared to a EU average of $81 \%$ ) but basic digital competences are still very low (44\% in 2017 compared to a EU average of 57\%): in both sectors Italy ranks $25^{\text {th }}$ out of the $28 \mathrm{EU}$ countries. Italy gained its worst position, $27^{\text {th }}$ out of the $28 \mathrm{EU}$ countries, when talking about online activities from those who surf the web; according to the report "Italy has failed to make progress on internet use and remains second to last". Except for music, videos and games (79\% in 2016) and social network (61\% in 2017) where we are almost in line with EU average (78\% and 65\%), everything else such as internet banking (43\%), e-shopping (44\%) and e-news (56\%) is well below EU average $(61 \%, 68 \%, 72 \%)$. The situation is getting better with the integration of digital technologies where, as for the digitisation of the firms, Italy is trying to bridge the digital divide going up and even if its overall score increases from 33 points to 36.8 points it fell from $19^{\text {th }}$ to $20^{\text {th }}$ as other countries made faster progress. Italian companies are above average users of electronic information sharing $\left(13^{\text {th }}, 37 \%\right.$ compared to a EU average of $34 \%$ in 2017), radio-frequency identification $\left(11^{\text {th }}, 5.2 \%\right.$ compared to a EU average of $4.2 \%$ in 2017$)$ and eInvoicing $\left(5^{\text {th }}, 30 \%\right.$ compared to a EU average of $18 \%$ in 2016), even if e-commerce is not very common among the PMI ( $7.9 \%$, compared to a EU average of $17.2 \%$ in 2017). Lastly, in the digital public services, Italy is making slow progress and it is stocked in $19^{\text {th }}$ place, even if there has been a wide increase in using open data (from $52 \%$ up to $81 \%$ in one year) far above EU average (73\%), there is a short use of e-Government services, almost half of the EU average (20\% compared to a EU average of 58\%).

We have to focus on that data and, starting from it, plan the future investments and implement the necessary solutions aimed at achieving competitiveness, thanks to the dematerialisation of the administrative procedures and acts. If we succeed in carrying this out, we will have a faster and more efficient Public Administration, able to reduce, thanks to the new technologies, the gap with the citizens and repaying them with some spare time to spend as they like instead of queuing up and waiting in a Public Administration office.

\subsubsection{Long Term Investment to Sustain the Innovation Process}

Every process of change and introduction of new technologies, in order to be implemented, require not only time but constant consistent funding. Zero-cost reforms are not possible in the Public Administration, we need long-term investment in order to realise the revolution which is going to reform the administrative machinery but also to have fresh resources available to start and implement innovation projects and let them spread all over the territories. We then need public resources in order to provide the Public Administration with technological infrastructures and computerized systems. A public sector investing in innovation and renewing itself attracts private funding making the private investor willing to become a partner in that same innovation project. This brings new money and at the same time encourage the private sector to innovate as well, challenged by the possibility to create new solutions for the public services. Creating synergies with the private sector will help Public Administration to overcome its internal restrictions regarding public finances. Sometimes zero-cost reforms are dictated not by a real desire of renewal but are just the consequence of budget linear cuts imposed by the government.

The Public Administration should not only relate and find funding from the private sector, it should also take the opportunity to use the structural funds offered by the EU, especially those linked to innovation. It would be appropriate here to make a light observation in a period where the popular sentiment of belonging to the EU values and seize the opportunities provided by membership of their country in the EU has been falling. The economic crisis has surely speeded up the decline in confidence in the EU values especially as the solutions proposed by the EU Institutions have often failed to meet the needs of the citizens. Much of the time the EU people consider the Community institutions as entities imposing them constraints and assigning tasks giving them nothing back in terms of services and welfare. That is why it is necessary to intercept the Community funds and ensure the optimum use of them, developing an innovation policy and a digital transformation of the Public Administration: in doing so we will not only provide new services and meet new needs but will bring EU institutions closer to its citizens.

The current climate of mistrust on these issues will probably affect the political debate and the old rooted opinions could preclude from taking innovation measures and see EU as a partner. In order to avoid this to happen it is important to underline that, even if there are critical positions regarding the EU policies, we can't mask the fact that we are unable to use EU resources and that can't be a pretext in not making a decision. We have to take advantage of all the opportunities provided by the EU to acquire knowledge and experiences and also take the best practises from other EU member states in order to replicate them or create new ones in our country.

Consequently, we need to lure the EU funding with a good planning, be able to use these resources and complete good projects. There is a discrepancy among the different areas of our territory, some regions are more deserving than others in 
making good use of the EU resources, but that is a field still in need of expertise. One of the main causes of this asymmetry is certainly the different grade of preparedness of the regional administrations, which can only be filled with the right investments, human resources in permanent training in order to equalise the competences among regions and ensure an evenly and balanced growth, in line with European standards.

Central Administration should restore uniform standards in staff training, improving the allocation of resources in the local bureaucracies where the administrative competences and culture varies greatly, where there has been a higher degree of backing down especially in the southern regions. It is not just about European funds. There is no need in having an office dealing with European affairs in a small town. More likely, in those areas there are no competences nor interest in developing solutions involving different communities. What we need is a coordination work, coherence between the solutions already at hand and the methodologies to properly implement them which is often possible with few resources and a clear strategy.

A clear example could be the one implying the deployment of the measures within the Italian strategy for digital growth, Strategia per la Crescita Digitale 2014-2020 (2016) - which is a part, along with the Italian strategy for next generation access network, Piano Nazionale per la Banda Ultra Larga AGID (2014), of the Italian digital agenda, Agenda digitale italiana - such as the Italian digital register of population, ANPR (Anagrafe Nazionale per la Popolazione Residente) and the Electronic payment system for the Public Administrations PagoPA (an Electronic payment system for the Public Administrations), or even the provision of a public Wi-Fi connectivity system in order to be vertically widespread at different level of the Administration, need a lot of resources and a clear strategy.

The funds Central Administration gives to Local Authorities should be used to modernize its technological infrastructure, clean and line up its database and adapt its software to match the solutions. These solutions, especially in the smaller communities, will require few resources and should sometimes be graded on different towns (delivering them to the unions of municipalities or to the Italian Provinces) as some services have to be handled together, in accordance with the provisions of the Law 56/2014 (the so-called Delrio reform, named after the former Italian Minister for Regional Affairs and Autonomy) or simply because the best economies of scale for that service and for the implementation of a particular solution are in a supra-local dimension. Anyway, if the aim is to fulfil the lack of efficiency and the technological gap in service provision among Local Authorities, we should avoid competitiveness and incorporate them in the same inclusive programme under the supervision of a higher administrative body as AGID. In conclusion, investments in innovation technology need long time to spread their benefits and often this is not what politicians seeking plaudits in the short term would pursue. On the contrary, a good politician does have a long-term vision and will invest in innovation in order to guarantee more financial resources which will help modernise the administrative body in the name of efficiency and will ensure in-service training of civil servants.

\subsubsection{Sharing Experiences and Reusing Solutions to Spread the Innovation}

Once the Central Administration has been able to create the right field where the innovation process can grow and develop through the territories, it is then necessary to reuse and share the experiences and let them pass all over the country, or at least in those municipalities which can adopt them. When there is a problem or we are looking for a better way to deal with something which already exits, then we come up with a solution and try to implement it. In the Public Administration, we already have solutions for the majority of the problems but we can find solutions to a lot of new challenges if we join our forces (and competences) or we go national and do not operate on a local scale. These solutions exist because they have been used in another reality or are now common practice in that area and they are not known anywhere else just for lack of communication.

This inefficiency affects the wellbeing of the community because it entails welfare costs (failure to respond to a specific need), political costs (there is a decrease in the quality of the government) and also financial costs (the need to invest in resources, starting from the beginning, in order to find a solution). It is then necessary to create a network of practices and experiences if we want to foster the culture of innovation and see it implemented all over the country. Reusing IT solutions and sharing experiences are the key to the know how diffusion which is essential in order to bring new practices in different territories, to take note of the best practices in research and development provided by others, to know in advance the unsuccessful attempts and what has failed. Reusing IT solutions among Public Administrations, reduce or cancel r\&d, sales and implementation costs and avoid also lock in mechanisms; an IT software, with an open source licence, can be freely used, modified, and shared too. The reuse is also part of the Italian eGovernemnt Code, Codice dell'Amministrazione Digitale introduced by the Legislative Decree n. 82/2005, as amended, where there is a specific section (Capo VI) on the development, acquisition and reuse of informatic systems in the Public Administration.

In this contest it is important to underline that the process of diffusion is not motu proprio, there is no guarantee about the success of the transferability in different realities. There are some findings we have to consider and without the presence of a motivational Central Administration and a clear regulation these can't be overcome. Just think of the obstacles related 
to the patent system and the intellectual property or the costs of implementation. In particular, the development of some projects in such territories needs a long trial period and high research costs, which can hardly be recovered (sunk cost) and therefore incurred by the Local Authorities. We can also incur technology skipping, when it is not convenient for a Public Administration to switch to an innovative technology, as the costs involved will outweigh the benefits. In this case it is really important that the Central Administration funds the basic research, through programmes able to involve Universities, research institutions and companies, contributing non-repayable money where needed among the Local Authorities.

In conclusion, the Central Administration must be the leader of this innovation process by giving a long-term vision, devising policy strategies able to achieve the goals already set out, demonstrating how our work in law-making can be slim line and forward-looking and our justice system more efficient and with fixed deadline in order to regain competitiveness and ability to invest and attract resources where needed: this is what makes innovative experiences develop and reused by Local Authorities. Central Administration and Local Authorities must work together, as allied, to ensure that Italy will be considered as an analogue country, an international example, when talking about innovation in Public Administration.

\subsubsection{Local Authorities, Where Innovative Tools for the Public Administration Arise}

Local Authorities are therefore the other side of the coin, who's some features have been depicted so far as a reflexion of the Central Administration' functions. And that is how it should be because it is impossible to see these two entities as two watertight compartments: there really are points of contact and mutual interactions over and above the individual differences which exist and must be carried out. After analysing the role of the Central Administration, we have to define now the role of the Local Authorities, especially those aiming to be examples of innovative practices in the Public Administration. Their role consists in the ability to intercept and determine the real needs of the citizens and detect where to act and with the help of local stakeholders provide technological solutions and define the necessary instruments to implementation.

In order to define priorities, it is necessary that the Local Authorities analyse and intercept the needs of the community at hand, which is really what those in Government should do, both at Central than at Local level. There must be a deep knowledge of the territory, everything that needs to be done, the sites to be recovered and those to bring together for economic, territorial and cultural affinities. Therefore, there must be a deep and serious analysis involving all the stakeholders, necessary actors to make the representation of the reality the more complete as possible. Without this clearness it will not be possible to set priorities and define how the single actions should be carried out. Besides, this is also an important element because it qualifies Public Administration's action outwards, giving private entities the possibility to express their opinion on the quality of governance, on the prospects of development and growth and if and how the government action is in line with the local mission.

Once the needs are defined, we have to find the optimal solution, the right conditions to face and resolve the problem. Missing the yardstick means to fail in our mission to implement the process. Sometimes the solution is to be found in a larger scale. For example, in a service handled by various Municipalities, the Local Authority, once found the need, should be able to handle a political and administrative job, at all institutional level involved, in order to find a shared solution. That won't be an easy thing to do but it is similar to the one shared by the little municipalities when dealing with the neighbouring territories or the bigger entity having to organize and run local public services at a higher level of government.

Lastly, the Local Authority should adopt technologies and projects able to meet citizens' needs: again it is crucial to have an administrative structure able to achieve the solution and with a necessary funding to support it. More often Local Authorities lack these factors and that is where the Central Administration steps in, in order to offer continuous training in administrative and technical fields and provide resources to finance innovation projects and all within as much comprehensive plans as possible. Everyone has a rule: the Local Authority has the planning and the Central Administration promotes the measures aimed at supporting, improving and spreading the solutions in the same way across the national territory.

\section{The ELISA Program}

\subsection{An introduction to ELISA Program and Its Action Areas}

The ELISA funding program (Enti Locali - Innovazioni di SistemA, Local Authorities - System Innovation) is the most daring and successful experiment that the Central Administration has made in Italy. It was introduced by the Law $\mathrm{n}$. 296/2006 as an instrument to create a national fund for the investment and the innovation in the local authorities (2007 Finance Act) and in its decade of operation, it gave an important contribution to the organizational and technological modernization of the Local Authorities. The Department for Regional and Local Affairs became responsible for its 
management and, at first, the fund was financed with 15,000,000 € for each year (2007, 2008 and 2009) but then, the 2009 funds were reduced to $11,576,765 €$. This attempt can be considered as a precursor with respect to what would later be the prevailing attitude of those European policies which, in view of the challenges of the international economic crisis, responded favouring the local dimension of development. In practice, this has resulted in financing fewer but major projects, investing in innovation and Local Authorities, where technological innovation has fully shown it can be the lever for streamlining and enhancing public functions The ELISA program has therefore allowed and eased the rise of nationwide deployment models and eGovernment collaborative management. As a consequence, the Public Administrations involved in this matter have learnt to develop ways of working based on the aggregation and cooperation between the organizations, thereby laying the basis for the creation of regional knowledge networks able to produce tangible results.

Going into details, the ELISA program was created to finance projects developed by Local Governments, preferably aggregated with each other, that may encourage digitalization of administrative activity, have a national significance and whose actions are consistent with their respective regional plans and have also the goal to shorten distances and to reduce the digital divide in small towns, in mountainous and inland areas. Furthermore, they must enhance their own territories, ensuring their growth and improving, at the same time, the countrywide system, by achieving sustainable results that bring tangible benefits for citizens and business. Eventually, they must possess an innovative organizational model that may guarantee the aggregation and they must be built on the basis of standard parameters, so as to ensure the replicability in other contexts and territories.

The projects are developed in three main fields:

- INFO-MOBILITY: integrated management of logistics and info-mobility in local public transport in the urban and suburban public and private mobility. This means new systems for monitoring and managing fleets, for traffic control and regulation of traffic light cycles, for air pollution detection, management of gates in the ZTLs (Controlled Traffic Zone), for integrated ticketing, for the improvement of information available to users by exploiting the potential of the web and the mobile.

- QUALITY OF SERVICES: measuring systems based on ICT technologies so as to assess the quality of the services provided by Local Authorities. The goal is to improve services for users and the efficiency of its internal processes throughout advanced systems of Citizen Relationship Management (CiRM), highly interactive web portals, implementations to support the annual and multiannual programming, solutions for measuring organizational and individual performances, integration and upgrading of labour information systems (at the beginning, even though the labour-related projects were in a stand-alone group, then, during the assessment of the projects, they were absorbed by the quality of services field.).

- TAXATION AND CADASTRE: integrated digital management of local services concerning taxation and cadastre through cooperative application models. The aim is to increase the ability of overseeing and monitoring the territory, countering tax evasion and promoting tax equalization. Tax, civil registry services, construction industries: all these fields of application are now the backbone of the organisations that adopted them.

The Department for Regional and Local Affairs, in order to find projects in this respect and after defining the specifications for the assessment, admission and management of funding, has issued three Calls. The first one for 2007, the second one for 2008 and the third one for 2009. Eighteen projects were therefore selected (6 for each year), all interregional projects equally distributed all over the peninsula: 1,000 local authority employees and 200 municipalities, as pilot authorities or supporting them (spreading cities) in the development and in the installation phase, excluding the reusing authorities (the ones who only use the software). The total value of the projects amounts to $100,000,000 €$ : the info-mobility area attracted 43,720,000 €, 14,420,000 € from government funding and 29,300,000 € from regional/local funding; the quality of services area attracted $25,300,000 €, 11,300,000 €$ from government funding and 14,000,000 $€$ from regional/local funding; the taxation and cadastre area attracted $31,150,000 €, 12,300,000 €$ from government funding and 18,850,000 $€$ and regional/local funding. In conclusion, the Department for Regional and Local Affairs has planned that 5\% of the allocated resources were earmarked for matters of assistance and technical support for the assessment of the submitted and financed projects, for the verification, monitoring and implementation of the projects and for information activities and support to Local Authorities; the technical assistance of the ELISA program was entrusted to Invitalia s.p.a.

\subsection{The Financed and Implemented Innovation Projects}

What follows is an examination of the 18 financed projects, regarding the three Calls of ELISA program. These are the projects from which more than 70 modernization solutions for the Public Administration were devised. For each project there is the area of interest, the project leading proponent, the catchment area and the available resources. Then, the main features are described with cross-references to web sites in order to have an in-depth analysis available. 


\subsubsection{The Projects of the $1^{\text {st }}$ Call}

The first selection Call of ELISA program, whose winners were announced on the $18^{\text {th }}$ of February 2008, had been issued on the $1^{\text {st }}$ of August 2007. The funding received, that amount to a total of 36,400,000 $€$ (of which 14,200,000 $€$ are government funds and $22,200,000 €$ regional/local funds) were used to realize the following projects, which are described below:

- ELI-CAT (area: taxation and cadastre - leader: City of Bologna - catchment area: 13,500,000 citizens - gov. resources: $2,800,000 €-$ regional/local resource: 4,700,000 $€$ )

ELI-CAT project (http://servizi.comune.fe.it/6457/attach/superuser/docs/elicat_bp.pdf) as a decentralized cadastre tool, includes fields of application so as to develop ACSOR (Anagrafe Comunale dei Soggetti, degli Oggetti e delle Relazioni, a municipal registry office of population, instruments and relations), ACI (Anagrafe Comunale degli Immobili, municipal register office of buildings), Sportello Catastale Integrato (cadastre portal) and Il Portale del Contribuente (taxpayer portal). Ergo, it was created to integrate the databases of Local and Central Authorities in order to: streamline the quality of data available to public offices; update the database and correct the wrong or repeated data; support the action of the local cadastral offices and Mountain Communities that are prepared to manage the cadastre functions on behalf of small towns; ensure the flow of information between public authorities, citizens and business in order to promote transparency; harmonize the cadastre management processes to grant a proper control of the territory and pursuing tax equalization objectives. The project benefits from the regional co-financing of Emilia-Romagna, Liguria, Piedmont, Sardinia, Tuscany and Umbria. The pilot cities are Bologna, Genoa, Fabbriche di Vallico, Modena, Padua, Pesaro, Rovigo (with 48 municipalities of its province) and Terni and almost 2,000 Local Authorities countrywide already adopted it.

- ELI-FIS (area: taxation and cadastre - leader: City of Terni - catchment area: 20,600,000 citizens - gov. resources: $2,800,000 €$ - regional/local resources: 4,200,000 €)

The ELI-FIS project

(http://www.regione.toscana.it/documents/10180/70234/progetto\%20eli-fis/7c376a0b-0a0c-4e92-8eb6-b6380cbea4 f6) implements the federal taxation through the integration of local and national databases. Over time, a data warehouse was created in order to analyse the local taxation. The aim is to recover evasion of local tax and any other tax. The aim is also to analyse tax burden through business intelligent tools. This leads to the creation of a control framework called "Dashboard for fiscal federalism", through which Local Authorities can plan and manage their revenues. The project has thus allowed Local Authorities to properly manage and program their financial resources, to strengthen tax evasion recovery activities and to generate a flow of certain and planned activities for the subsequent years. This project has benefited from the regional co-financing of the regions Emilia-Romagna, Liguria, Piedmont, Sardinia, Tuscany and Umbria. The pilot cities are the municipalities of Ancona, Bologna, Fabbriche di Vallico, Genoa, Terni and Turin. But if you consider other funding institutions, it is possible to get to almost 2,000 Local Authorities countrywide.

- IQUEL (area: quality of services - leader: City of Parma - catchment area 4,900,000 citizens - gov. resources: $1,500,000 €-$ regional/local resources: $1,800,000 €)$

The IQUEL project (Innovazione e QUalità erogata e percepita dagli Enti Locali, perceived and delivered innovation and quality by Local Authorities) wants to install in the Public Administration the principle of continuous improvement (http://web.rete.toscana.it/riusosdi/static/IQuEL.pdf). It pursues the goal of developing a monitoring and assessment system of the services provided by Public Administration offices, including with benchmarking systems with other administrations, from which it will be possible to achieve concrete improvement actions and new services for citizens. The major local governments that have taken part in the project are the cities of Bologna, Florence, Modena, Piacenza, Reggio Emilia, the provinces of Brescia, Chieti, Padua, Parma, Pesaro-Urbino, Rimini e Vicenza and the regions Tuscany and Emilia Romagna that, together with Umbria, also co-financed the program; in addition to them, more than 500 Local Authorities from Calabria, Campania and Umbria have also taken part in this.

- LABOR (area: labour - leader: Province of Turin - catchment area: 26,700,000 citizens - gov. resources: 1,600,000€ - regional/local resources: $1,800,000 €)$

The LABOR project (Lavoro Azioni Benefici Organizzazione Rete, labour actions benefits organization network) aims to improve safety at workplace, to streamline the system of employment agencies by easing the consultation of online employment agencies through the arrangement of useful databases on labour issues (http://www.provincia.torino.gov.it/speciali/2008/progetto_labor/pdf/programma.pdf). By crossing the databases, it becomes possible either to carry out targeted controls useful to counter illegal work or to allow administrations to program more effective labour policies, since they have a more consistent database available. In addition to this, there 
is the convenience for the citizens to be able to consult this wealth of information and to produce documentation directly from home. The project started with the provinces of Milan, Piacenza, Teramo, Turin and then expanded to many other Italian provinces, from north to south.

- SIMONE (area: info-mobility - leader: City of Turin - catchment area: 3,400,000 citizens - gov. resources: 2,800,000 €- regional/local resources: 4,900,000 €)

The SIMONE project (SIstema Innovativo di gestione della MObilità per le aree metropolitaNE, innovative system of mobility management for metropolitan areas) aims to create a decision support system for the mobility (http://www.simone.5t.torino.it). Real-time traffic flows are mapped by using the vehicles for the acquisition of data, while citizens are provided with the collected information either on suitable devices installed in cars or directly in mobile devices. The citizens' benefits consist in having access to real time traffic information, whereas Local Authorities are provided with a smart and dynamic tool to be applied in the ZTLs (Controlled Traffic Zone). The project involved the municipalities of Bologna and Genoa and the provinces of Cagliari and Florence; it was cofunded by the regions Pedmont and Tuscany. The project, which ended in 2012, led to the establishment of a national reference model for the management of mobility and traffic data exchange (which can be used by other Local Authorities): in 2014 Turin was awarded the SMAU prize "eGovernment: the champions of reusing".

- WI MOVE (area: info-mobility - leader: City of Rome - catchment area: 5,700,000 citizens - gov. resources: 2,730,000€- regional/local resources: 4,300,000 €)

The WI MOVE project is a public mobility service (http://www.wimove.it) which aims to create info-mobility, city logistics and tourism services to be made available on a free metropolitan wireless network. In this way, traffic and pollution are consequently reduced and public transport is made more efficient and accessible. The implementation of this support instrument requires the installation of via-Wi-Fi interconnected access points in strategic areas, such as on poles, vehicles, creating a free network that provides information to users (bus arrival times, news, events, advertising, promotions for tourists, etc...). The project grants security (thanks to networked cameras) and, as far as the companies of public local transport are concerned, it aims to lower their costs of internal communications and their costs of printing tickets; moreover, it allows a smarter programming according to the needs of public transport routes. Currently, the city of Cagliari, Genoa, Parma and Rome, as well as the provinces of Genoa and Florence, use the services related to WI MOVE project, according to the needs of their territories.

2.2.2 The Projects of the $2^{\text {nd }}$ Call

The second selection Call of ELISA program, whose winners were announced on the $3^{\text {rd }}$ of February 2009 , had been issued on the $19^{\text {th }}$ of February 2008. The funding received, that amount to a total of $36,470,000 €$ (of which $12,820,000 €$ are government funds and regional/local resources: $23,650,000$ ) were used to realize the following projects, which are described below:

- FED-FIS (area: cadastre and taxation - leader: City of Rome - catchment area: 19,200,000 citizens - gov. resources: $2,800,000 €-$ regional/local resources: 4,950,000 €)

The FED-FIS project concerns fiscal federalism and it aims to produce integrated services for local and national taxation

(http://www.regione.toscana.it/documents/10180/70234/progetto\%20fedfis/3caee3a2-e678-45ee-91da-9b0603e8ef3

8). This new project is meant to develop, integrate and promote the countrywide spread of the actions taken by the ELI-FIS and ELI-CAT projects: the sharing of relevant databases for purposes of local and national taxation, the integrated systems such as the ACSOR (Anagrafe Comunale dei Soggetti, degli Oggetti e delle Relazioni, a municipal registry office of population, instruments and relations) and the "Dashboard for fiscal federalism". In addition to this, it develops a system for the improvement of tax collection and for the management of the payments in order to ensure the effectiveness and efficiency. What's more, it adds cartographic basis for the municipal services in order to improve spatial planning functions. Finally, the project establishes relationships with regions, Internal Revenue Services, Territorial Agencies, aiming to create an eGovernment system. The pilot cities are the municipalities of Bologna, Fabbriche di Vallico, Genoa, Modena, Padua, Pesaro, Rome, Terni, Turin and the province of Genoa. The project has a widespread distribution in more than 2,000 municipalities in the regions of the Abruzzi, Campania, Emilia-Romagna, Piedmont, Apulia, Tuscany.

- GiM (area: info-mobility - leader: Province of Milan - catchment area: 12,860,000 citizens - gov. resources: 2,800,000 €-regional/local resources: 8,900,000 €)

The GiM project (Gestione Informata della Mobilità, informed mobility management) is designed to promote and ensure the sustainable development of an effective and efficient model of widespread mobility (http://www.trasporti.marche.it/Gim/index.htm). This is done by provisioning centralized multi-channel services of 
public and private info-mobility, through the definition of standards and the implementation of unit testing and operative modules. Amongst these there are: the detection of traffic flow on urban and suburban level; the monitoring of traffic control and the interchange of traffic data on regional and metropolitan level; the management of public transport fleets, of heavy vehicles and of goods; the traffic forecast; the support to critical events (accidents, weather, construction sites, events, emergencies); the dissemination of information to users such as territorial and traffic data through intelligent poles and variable-message signs; the proposed guidelines for open source standard for electronic ticketing. The pilot cities are the municipalities of Cesana, Ferrara, Florence, Forlì, Milan, Piacenza and the provinces of Ancona, Ascoli Piceno, Ferrara, Forlì-Cesena, Macerata, Milan, Pesaro-Urbino, Piacenza, Ravenna, Reggio Emilia, Rimini, Rome.

- GIT (area: taxation and cadastre - leader: City of Milano - catchment area: 3,800,000 citizens - gov. resources: 2,400,000 €- regional/local resources: 3,500,000 €)

The GIT project (Gestione Intersettoriale del Territorio, cross-sectorial land management), aims to improve service and interoperability levels between sectors of municipalities, and between municipalities and other government departments (http://www.progettogit.it). This is possible by providing models of information management and models of ideal organisation of the participating municipalities so as to give solutions with the use of information flows of the IRS agencies and Territorial Agencies. This is done through platforms able to cooperate, develop and integrate the received information with the information of the Municipal Information System. One of the goals of the project is also to have on the one hand a support system for decision on fiscal matters; on the other hand, to have in the municipal offices of taxes, some concessions and an integrated system to support the cadastral management and the assessment of fiscal and urban development. The participating local governments are mainly in the regions of Lombardy, Sardinia, Veneto, Umbria.

- LOG-IN-MED (area: info-mobility - leader: Province of Catania - catchment area: 4,220,000 citizens - gov. resources: 1,620,000 €- regional/local resources: 2,500,000 $)$

The LOG-IN-MED project (LOGistica Integrata nel MEDiterraneo, integrated logistics in the Mediterranean) is based on ITS (Intelligent Transport Systems) technologies, able to ensure a better accessibility to the platforms and a better use of motorways of the sea, hence creating a relationship between the production and distribution system through secure and protected mobility corridors (https://www.cittametropolitana.ct.it/Repository/provinciact/Documenti/2016/id_52475/3_Capitolato_descrittivo_ del_Sistema_LOG-IN-MED.pdf). Through technological systems, you are allowed to track the ideal way for the transport of goods, thanks to the acquisition, processing and dissemination of information about the best transport offer for every kind of good. It takes into account delivery times and treatment specifications. It is organised on two integrated logistics platforms along the territorial corridor and complementary along the motorways of the sea, which connect to the Meridian Corridor of the Tyrrhenian and Adriatic routes up to the Ionian ones. Finally, the project implements innovative remote monitoring systems that guarantee safety in correspondence of the interchanges and all along the corridor of the goods mobility. Local Governments who partecipate are the Provinces of Caltanissetta, Catania, Enna, Reggio Calabria, Ragusa, Syracuse, Viterbo and the municipalities of Aliminusa, Ancona, Caccamo, Cerda, Città di Castello, Gela, Genoa, Leghourn, Montemaggiore Belsito, Sciara, Terni, Viterbo.

- SCACCO (area: cadastre and taxation - leader: City di Salerno - catchment area: 2.570 .000 citizens - gov. resources: $1.500 .000 €-$ regional/local resources: $1.500 .000 €$ )

The SCACCO project (Cooperazione Applicativa Catasto COmuni, system of cooperation and application of cadastre in municipalities) was founded in order: to streamline procedures and reduce waiting times so as to simplify the compliance between citizens and businesses: to improve the flow of data and information in the domain of cadastre and taxation between local and central government (http://www.comune.salerno.it/client/scheda_news.aspx?news=2070\&stile=7\&prov=3). The solution foresees the creation of a unified database on which the data from municipal information systems converge. From here, it is possible to develop web services that allow Local Authorities to produce a better efficiency and effectiveness in quantification, collection and management matters concerning local taxes, thus ensuring a better governance, a better special planning and territory control to prevent unlawful building and tax evasion. The project now involves 200 Local Authorities in the regions of Basilicata, Lombardy and Campania, where there is the highest number of them.

- SdM (area: quality of services - leader: The Union of the Towns of Grecia Salentina - catchment area: 2,550,000 citizens - gov. resources: $1,700,000 €$ - regional/local resources: $2,300,000 €)$

The SdM project (Suoni della Memoria, sounds from memory) aims to promote the recovery, preservation and enhancement of the intangible heritage of musical traditions through its digitalization, archiving and later its translation into contemporary languages in order to make it accessible to the general public, in particular to young 
and elderly people (http://www.suonidellamemoria.it). In addition to preservation, the project aims to tourism and economic promotion of the territory and contributes to the implementation of educational activities and computer literacy activities in order to reduce the digital divide. The project involved the municipalities in the regions of Basilicata, Campania, Lazio, Apulia, Umbria.

2.2.3 The Projects of the $3^{\text {rd }}$ Call

Lastly, the third selection Call of ELISA program, whose winners were announced on the 19th of May 2010, had been issued on the 2 nd of December 2009. The funding received, that amount to 27,300,000€ (of which 11,000,000 $€$ are government funds and $23,650,000 €$ are regional/local funds) were used to realise the following projects, which are described below:

- CONCERTO (area: info-mobility - leader: City of Perugia - catchment area: 4,945,654 citizens - gov. resources: 2,400,000€- regional/local resources: 4,100,000€)

The CONCERTO project (http://concerto.prsmonitor.info/concerto/) has the objective to optimize travelling within the city/ province by encouraging the use of vehicles with a high standard of eco-sustainability. In particular, new forms of accessibility and traffic flow control are developed so as to monitor city centres, protected areas such as natural parks, reserves and areas of archaeological interest. In order to implement the project, it will be used a paperless, contactless, modular and interoperable system of accreditation based on parameters related to loads, means if propulsion, efficiency and security, both in distribution and urban collection of goods (city logistics) and in relation to transport services of passengers concerning the tourism industry. For the realisation of CONCERTO project, there are the contributions of the municipalities of Chieti, Florence, Genoa, Parma e Perugia, the provinces of BAT, Catania, Messina and Palermo. Additional partners of CONCERTO project are the towns of Pescara, Fermo and San Giovanni Rotondo, as well as the Mountain Community of Monti Sabini.

- $\quad$ ELI-ComUni (area: quality of services - leader: Province of Pescara - catchment area: 4,448,320 citizens - gov. resources: $1,500,000 €$ - regional/local resources: $1,500,000 €)$

The ELI-COMUNI project (ELISA COMunicazione UNICa, ELISA unique communication) concerns the domain of digital identity management and it foresees the implementation and testing of a package of services aimed at improving the integration of the civil registration offices deployed on the territory (http://www.elicomuni.ancitel.it). In particular, the project works in the field of simplification of relations between municipalities, businesses and citizens involved in the management and use of vital statistics. The project aims at the deployment of a series of eGovernment services including: direct vital statistics query through certified gateways; the notification of changes in vital statistics to third parties; the monitoring of information flows. In addition to the Province of Pescara, the project partners are the Province of Teramo, the municipalities of Carmignano, Montemurlo, Prato, Rome and Teramo, the CST Ali "ComuniMolisani", Chieti and Sulmona.

- ELI4U (area: quality of services - leader: City of Cesena - catchment area: 5,321,225 citizens - gov. resources: $1,500,000 €-$ regional/local resources: $1,500,000 €)$

The ELI4U project focuses on urban and environmental safety issues, and land management (http://www.comune.cesena.fc.it/progettieuropei/nazionali-ELI4U). It provides Local Authorities with tools, methodologies and organizational and technological elements to streamline the supply of the services in a continuous and stable way over time. The main objective is to create an integrated framework that may maximize the service provided to users, and may bring an internal increased efficiency through: a qualification and support system of planning the annual and multiannual programming and planning the internal and external relationship management evolutionary systems. The municipalities involved in the project are Barletta, Bologna, Brescia, Cesena, Como, Florence, Forlì, Leghorn, Milan, Modena, Padua, Piacenza, Ravenna, Sesto Fiorentino, Sondrio, Venice, Udine together with the regions Tuscany, the district Empolese Valdensa and the district S.I.R. Umbria/Mountain Community Valnerina.

- $\quad$ ELISTAT (area: quality of services - leader: Province of Brescia - catchment area: 23,500,000 citizens - gov. resources: 2,000,000 €- regional/local resources: 2,400,000 €)

The ELISTAT project aims to create and share an integrated system of statistical indicators related to all the functions and services provided by the Provinces, with a focus on services for small municipalities, in order to measure their performance

(http://www.provincia.catania.it/informazioni/progetti/informatica/allegati/progetto_elistat.pdf). In order to achieve its goals, the project is based on 5 sectors: project performance monitoring system; user satisfaction survey system; web marketing monitoring systems; system for assessing the introduction of ICT services via CTS, Territorial Services Centres / ALI, Local Alliance for Innovation; Provincial observatory and benchmarking of the first four 
sectors; digital identities integration system. The project involves more than 40 Provinces located in 12 Regions spread throughout the peninsula.

- INFOCITY (area: info-mobility - leader: Province of Naples - catchment area: 16,964,400 citizens - gov. resources: 2,100,000 €-regional/local resources: 4,600,000 €)

The INFOCITY project was created in order to implement a customizable multimedia info-mobility system that can organize databases of various public and private transport operators so as to allow the user to get, before and during the itinerary, to (static and dynamic) customized and real time information, on the transport system and mobility, also related to cultural and touristic information

(https://www.comune.lecce.it/amministrazione/settori/innovazione-tecnologica/progetti/infocity). In particular, some of the implemented services are: traffic monitoring service with detectors located on the fleet of buses circulating in the province so they can provide evaluation criteria to determine the general traffic situation; services of customized information dissemination based on the user own interests. It is available in various devices (from smartphones to kiosks, to information poles) and keeps the user updated with respect to traffic, suggested itineraries, connections with public transport, tourism services. The involved municipalities are Bari, Brindisi, Lecce, Perugia, Rome e Turin. The Provinces involved are Bari, Brindisi, Florence, Lecce, Milan, Naples, Potenza e Turin.

- SiCom (area: quality of services - leader: City of Prato - catchment area: 2,437,391 citizens - gov. resources: $1,500,000 €$ - regional/local resources: $1,600,000 €)$

The project SiCom (Sicurezza in COMune, municipalities safety) was created to experiment new technologies and systems for urban safety for municipalities in order to provide the Local Municipal Police Headquarters with the tools and systems to operate both in mobility and in fixed stations (http://sicom.ancitel.it). This happens thanks to the creation of an infrastructure that allows a real time access to databases. It allows to acquire real time information on stolen vehicles and their insurance status, on lost or stolen documents, on residence permits status. It is helps the collection of reports and their transmission to judicial authority's certified electronic mail address. It is useful to detect the identity of a driver and immediately verify the actual ownership of the vehicle; to report, monitor and report to the structures designated by the Ministry of the Interior. The involved municipalities are Arezzo, Asti, Bari, Fermo, Forlì, Genoa, Mantua, Parma, Piacenza, Prato, Siena, Treviso, Venice, Verona.

\subsection{The Benefits of the ELISA Projects in the Local Communities}

Not only has the implementation of these projects given the intangible benefits such as the increase of know-how and expertise of Public Administration, it has also generated much more tangible benefits, such as money savings and economic benefits from the supply of new and more efficient services to citizens as well as reducing the time for carrying out the bureaucratic practices. A complete analysis aiming at reckoning a balance of ELISA program and to quantify its (economic, managerial, social, environmental, commercial) impacts has been carried out, as foreseen by the first course of action of eGovernment laboratory ( $\$ 3.1$ ). The analysis is contained in the study of Reti di Città Intelligenti - Risultati e Prospettive del Programma ELISA (Smart City networks - Results and perspectives of ELISA program) by the Department for Regional and Local Affairs and the Politecnico di Milano - School of Management (2014). Below, some results for each of the treated areas are listed.

In the info-mobility area, it is stressed that the municipality of Perugia has achieved a saving of $250,000 €$ per year thanks to the digitalization of the procedures for the authorization of transiting in ZTLs (CONCERTO project). The city of Turin has decreased by $10 \%$ the average travel time in urban areas (SIMONE project); thanks to the introduction of speed cameras in the province of Milan, from 2009 and 2011, road traffic deaths decreased by 29\% and injuries by 14.5\% (GiM project); expanding the wireless network in the city of Florence has allowed 4,400,000 Wi-Fi accesses in 2012, and the implementation of intelligent traffic lights with LED light in 2011 has brought to a reduction of $361.000 \mathrm{kWh}$ consumption and to a decrease of 500 tons of carbon dioxide production. (GiM and WI MOVE projects).

In the quality of the services area, the provinces of Brescia has developed customer satisfaction survey systems through on the "emoticons - let's face it" system, for measuring the perceived quality (ELI-STAT project); the municipality of Cesena reduced by $30 \%$ the efforts to manage the process of planning and monitoring, and tripled its political effectiveness; the city of Padua achieved a saving of $1,000,000 €$ per year for the digitalization of its internal processes and the city of Parma has reduced by $90 \%$ the accesses to their offices by making businesses achieve a saving of 4,400,400 € per year (ELI4U project); finally, as far as the work area is concerned, the province of Turin has achieved savings amounting to $1,800,000$ $€$ in 2012 thanks to the new provincial portal centre for employment (LABOR project). That year, 24,944 enrolments were registered and 16,000 online certifications were issued.

In the tax system and cadastre area, for example, in the city of Rome the time for an accounting or a tax reconciliation practice decreased from 2 hours to 20 minutes (FED-FIS project); in the municipalities of Milan and Bologna, the 
integration of tax and cadastral data of Territorial Agencies and Internal Revenue Services allowed a tax revenue recovery of 16,500,000 $€$ in two years. In Bologna, tripling the fiscal controls has led to a fifteen times higher average increase in tax revenues (ELI-CAT and ELI-FIS projects). In Milan, the revaluation of existing cadastre system allowed to total $1,500,000 €$ (GIT project). Moreover, the national dissemination of information for the automatic calculation of the municipal tax, would allow citizens to save $22.5 €$ for each cadastral position, equal to a quantified saving of around $1,500,000 €$.

\subsection{Light and Shade of the ELISA Program}

In order to carry out an evaluation in terms of relationship between Central Administration and local administration, we could say that the first one has complied properly with its functions. This was done by supporting the Local Authorities, not only in the first stages, but also throughout all the processes of implementation of the projects; by supporting interventions and exerting constant and widespread controls, thus ensuring uniformity and cohesion to the principles of the initiative. However, taking into account the ELISA program experience, it becomes necessary a more detailed analysis on what has and what hasn't worked. Not only is it necessary to trace (and report to citizens) a tout court balance, but also to understand what has to be corrected, where it is better to keep investing, and where it is better to change course.

These assessments are made taking into account the principles of the first chapter, that might be useful for a comparison in order to assess the strengths and weaknesses of the ELISA project. As far as strengths are concerned, the program represented the first attempt on the theme that was realised and implemented by a Central Administration able to have foresight and the ability to spot the need for innovation of Local Authorities. The ELISA program has therefore guaranteed them support but, most importantly, has left them free to define the planning, not imposing any will. The project has created the right conditions to obtain a suitable environment for developing planning. In particular, three aspects have positively characterized this experience: a continuous follow-up, which has given attentions to the projects, but it has also allowed quite a sensitivity to incentivize the chances to create a network and share experiences; definite resources, provided on default plans, and provided for a mid/long-term period, so as to allow local governments to achieve their projects; finally, if the project had a positive feedback, that's because it had been foreseen a careful and accurate scouting activity on the themes concerning the Calls. This activity has indicated the sectors on which local governments' interest and planning will stream.

However, ELISA program has showed weaknesses and gaps, too. They can be identified in relation to the ability that the Central Administration and the local governments had in performing the functions they were supposed to perform, as well as the characteristics they were supposed to have. Taking this into account, the first limit that emerges is the one concerning the effort, for the implementation of the ELISA program, that the Department for Regional and Local Affair has made. This effort was made in an historical period characterised by the absence of a political vision able to guide the country's politics.

In addition to this, the same financed projects were not coherent, even detached, with respect to the development plans of the city. They were not included in a local strategy that, essentially, marginalised them and kept them away from private funds. As a consequence, the projects were kept away from the possibility to lure resources that would have allowed to proceed, in future, mostly in an autonomous way, once that the funds of the Public Administrations were used up. All this resulted, especially in the less developed areas, an inability of the project to establish roots in the territories that hosted them. Therefore, when they came to an end, the conditions to set up new projects were not established.

Finally, and this point concerns all the projects, the fact that the ELISA program has had three-year limited funding has not allowed the proper support and assistance along with the impossibility to replicate these projects, a feature which has always been appreciated and has proved to be useful for local governments.

\section{From the ELISA Program to the Innovation Communities}

\subsection{The eGovernment Laboratory, Objects and Action Areas}

The eGovernment Laboratory (http://www.labegov.it) was created by the Department for Regional and Local Affairs to remedy the weaknesses emerging from the ELISA program and to provide continuity to the projects that have shown significant impact on the territories, in order to replicate them and disseminate these experiences throughout the country. This initiative arised from collaboration among the School of Management of Politecnico di Milano University and Invitalia s.p.a. - the National Agency for inward investment and economic development, owned by the Italian Ministry of Economy - and was realised thanks to the funds generated in the management of the 2007-2009 funds of the ELISA program. In July 2012, two agreements were signed: the first, called Progetto azioni di sistema negli Enti Locali - Reti di città intelligenti (System measures project for Local Governments - Smart Cities Networks), to support and strengthen the innovation process in Local Governments launched by the ELISA program; the second, called Programma ELISA - Reti di città intelligenti: Laboratorio eGovernment (ELISA program - Smart Cities Networks: eGovernment Laboratory), to 
spread countrywide the organizational and technological standards of the innovation process achieved by the organizations concerned with the ELISA program.

The eGovernment Laboratory therefore had as its main objective to provide support and coordination to the development and dissemination of good practices across the Italian territory, with a look at international experiences and trying to overcome the limits that the reuse mechanism has as shown so far. In particular, the eGovernment Laboratory has carried out activities concerning analysis, verification, coding, projects impact assessment, elaboration of dissemination and sustainable management of the results achieved by Local Authorities. An action that enhances the heritage of the projects, supporting the creation, extension and consolidation of networks around best practices. The work of the Laboratory has made it clear that there is a need for development as well as the need to introduce more stable and effective Innovation Communities (or territorial knowledge networks) useful to promote the implementation of sustainable and self-sustaining innovation management models and to disseminate the results, by transferring knowledge among the Public Administrations. In this respect, the eGovernment Laboratory has highlighted five pivotal areas of action:

monitoring, in terms of incremental developments and adoption processes, the best solutions developed within the ELISA program with reference to the domain within which the projects are realised (cadastre and taxation, info-mobility and quality of services);

enhancing the consolidation and the organisation of Innovation Communities, that rise among the most successful projects so as to enable the transfer of knowledge and skills between Local Authorities and facilitate the adoption of organizational models that will ensure replication;

support Local Authorities in the adoption of organizational, managerial and technological models that aim to strengthen governance ability in accordance with Law n. 56/2014;

analyse and promote the spread of over-municipal coordinated management models of innovation in accordance with Law n. 56/2014;

outline the institutional scenario traced by Law n. 56/2014 by deepening the theme of the Metropolitan Cities, studying its role in relation to that of their capital cities and other reference authorities, studying how to link it in a strategy to help improve its programming capacity.

\subsection{The Innovation Communities, Analysis Mode and Deployment of Solutions}

As far as the first course of action is concerned, the outcome that the eGovernment Laboratory monitoring activity on the ELISA program projects, was earlier illustrated when an account was taken of the positives and benefits of the solutions territories adopted $(\$ 2.3)$. For the purposes of this section, the second course of action should be considered, that is to say how the eGovernment Laboratory has been deciding to enhance the consolidation and organisation of Innovation Communities, that rise among the most successful projects. Consequently, it will be eased the transfer of knowledge and skills among Local Authorities. Moreover, the implementation of organisational models that ensure replicability will be facilitated.

To better understand what a community is and how it works, we will take as an example the community grown up around the institute for the finance and local economy IFEL (Istituto per la Finanza e l'Economia Locale), a foundation established in 2006 by the national association of Italian municipalities, ANCI (Associazione Nazionale dei Comuni Italiani) in order to give financial and economic assistance to the Italian municipalities. The IFEL community was created to promote the dissemination of application solutions developed by the Public Administrations on cadastre and taxation; this happens thanks to tools such as SemplifiSco (http://www.semplifisco.anci.it), aimed at strengthening the technical skills and governance of the local authorities, with the aim of ensuring the progressive development of any useful synergy for countering tax evasion, according to the criteria of administrative effective collaboration.

More specifically, the action of the IFEL community intends to pursue: a greater awareness of the role of Municipalities in the fight against evasion and organizational and management requirements; the strengthening of (institutional and operational) cooperation between municipalities and other parties involved in the fight against evasion; the widest sharing of solutions and dashboards to support local taxation, already effectively tested by municipalities and Local Authorities, and which have shown significant results with the aim of promoting the reuse of such tools in other territorial contexts. In conclusion, although it is not part of the ELISA program, the IFEL community has a great potential, due to its technological tools network, used to operate more efficiently on delicate issues such as taxation and cadastre: a set of solutions that can be transferred to other contexts through the conclusion of protocols with local participants.

\subsubsection{How to Profile an Innovation Community: Analysis Elements}

The work done by the eGovernment Laboratory has led to the design of a framework within which all the different forms of community could be brought together, identifying the elements to consider: the mission, the strategic goal; the participants, the subjects involved, and with what role in the community; the services provided to the various stakeholders 
(training, evaluation of reusing local authorities, software selection, support for the transfer of solutions); governance, how to coordinate and govern the community; the sustainability of the community. To ensure this sustainability, it is necessary the knowledge of the structure, of costs, sources of revenue.

In relation to the analysis domains, the IFEL community can thus trace this profile:

mission: strengthening the technical and governance skills concerning the governance of local administrations regarding taxation and countering tax evasion;

participants: Local Authorities, no formalized entry procedure;

manager: IFEL Foundation;

services provided: training, evaluation of the organisations with respect to regulatory compliance and software selection;

governance: a model of governance and linking with stakeholders is not defined;

sustainability: projects are financed by the Presidency of the Council of Ministers - Department of Public Function, but no sustainability model has been identified yet.

\subsubsection{The Solutions Deployment Through the Mechanism of the Innovation Communities}

The next step was to support the dissemination of good practices through long-term sustainable and self-sustaining community models that allow to provide significant benefits by transferring knowledge among Public Administrations. To do this, the identification of target subjects was firstly done. Secondly, the modelling of the parts that allowed the deployment of a community was made. Thirdly, and finally, it was drawn the development solution scenario for target subjects.

The target subjects' selection was achieved by selecting, among the experiences that were examined, the suitable ones, after analysing the operating model, the impact assessment in the places where they were deployed, and the sustainability of the communities.

The second step was about tracking down the elements supporting the deployment of a structured Innovation Community. From a methodological point of view, the community, after analysing and comparing several innovation management experiences, must be inspired by at least three principles. Firstly, it is necessary to define a mission that aims at: enhancing good practices developed and promoting their dissemination at national level; encouraging a virtuous and sustainable exchange of knowledge and skills, including by involving the market of professionals and businesses in the community activities and processes; engineering the process of transfer, management and evolution of solutions through the definition of standards and appropriate organizational, technological and administrative tools; ensuring the maintenance and upgrading of the solution, making it available to the community by uniquely identifying roles and responsibilities. Secondly, all the stakeholders around the community must be clearly identified, in particular the interested organisations, the market and institutional partners (Department for Regional and Local Affairs, Politecnico di Milano and Invitalia s.p.a.). Finally, third and last point, participants must be involved in the management and transfer of the community's solution.

So, here it comes the last step, drawing the development solution scenario for target subjects, defining the role of participants, with the aim of triggering sustainable mechanisms to support the management, diffusion, and development of solutions.

3.2.2.1 Transfer, Management, Animation: The Three Stages to Implement the Best Practise within the Innovation Communities

The deployment consists of three phases: the transfer of the solution, its management, and finally the animation. A process that involves assignor community along with institutional partners, reusing local authorities, and the market that, at all stages, have specific tasks. To illustrate this, we take the IFEL community as an example by reviewing all the phases.

The transfer phase consists of six steps: IFEL receives requests from other local authorities and reports from the partners and schedules presentations (requests); IFEL, together with the partners, shows the solution to the interested local authorities and verifies its applicability and, in the meantime the local authority collected the information necessary to make its own assessment (presentation and evaluation); the reusing local authority signs the agreement with the one which has already implemented the solution on the basis of the modules formulated by the institutional partners and under IFEL, that deals with the merger function (reuse agreement); under the supervision of institutional partners, the standardized IFEL solution will be implemented by the market at local authorities whose staff will be formed on the solution (installation); under the supervision of institutional partners, the market carries out the introduction of the solution in the local authority, by initiating training, if necessary, of the local market and the organisation itself (training); IFEL closes this phase, which intervenes in support of the organisations to identify, in the market, qualified suppliers who will then assist the organisations, always under the supervision of institutional partners (assistance). 
After the transfer phase is over, the three-step management solution phase is carried out: IFEL monitors and, according to the reports from institutional partners, market and local authorities, evaluates whether to implement software changes (monitoring); IFEL participates and coordinates the activities of the Technical Committee to approve the changes to the solution that the market is required to develop, committee members and the participation of institutional partners are determined by the agreement (development); finally, with the support of institutional partners, IFEL ensures upgrade of the reuse kit, which the market needs to provide according to defined rules, including all the changes made and making them available to the community and the local authorities that can ask for an update (update).

The last stage is animation, and it consists of three steps: institutional partners, but also the market and the local authorities, are active promoters of the solution at national level through targeted initiatives within their ordinary business activity while IFEL coordinates communication activities continuously (communication); local authorities present the themes of interest and, on the basis of these, IFEL coordinates the activation of working groups aimed at animating the confrontation between different community participants on shared interests, while institutional partners also support by involving experts (working groups); finally, if the local authorities show training needs, then IFEL activates and coordinates the activity, leaving the market and institutional partners an opportunity to report experts (training).

\subsubsection{The Benefits of the Innovation Communities}

Innovation communities have advantages in managing innovation with respect to the local authority, which realizes and manages alone the individual project. The communities allow participants to create projects and transfer knowledge among the Public administrations so that, inside the communities, information, good practices and feedback can circulate freely; in this way a wealth of knowledge is generated and consolidated and then it can eventually be shaped on the characteristics of a specific reality. In addition, the participation in a territorial network of knowledge leads to share common goals, built together, in which each local authority can recognize and thus stimulate and ensure replication.

In addition, the community presides and monitors all the prior phases regarding the reuse of Public Administration's technological and organizational solutions: analysis, assignment and evolution. Specifically: it evaluates the compliance of the candidate-to-transfer solution; acquires the know-how for their diffusion, management and evolution; handles transfer requests, triggering the Public Administration's assessment process; transfers the solution and know-how to the reusing Public Administrations and to the companies concerned; it finally governs the process of evolution of solutions with stakeholders.

In relation to the actors involved, the community becomes the meeting point between supply and demand for Public Administration innovation, by providing the organizational and technological tools that ease the reuse of good practices, overcoming their limits of a non-systematic management, generating widespread benefits. The assignor Public Administration may disseminate its solution to other Public Administrations, thus creating the assumptions of a possible future reduction in the management and maintenance envisaged costs; moreover, this would have greater support for the management of the community itself, thanks the possibility of accessing a larger set of skills. Instead, the receiving Public Administration has access to consolidated reuse solutions and qualified skills, benefits from maintenance interventions, provided that it has an ever-innovative product and, at the same time, it reduces costs, time and dependence on individual suppliers thanks to savings.

Finally, also companies that interfere and work in close contact with the Public Administration have undoubted benefits: in this framework they have a promotional channel for their business, they can access new markets, reduce business risks and can increase their skills thanks to the synergies that are generated. All this, of course, is also an immediate benefit for users of the Public Administration, for the citizens themselves, who appreciate a significant improvement in the services provided, and experience the use of innovative solutions to meet their needs.

\subsection{The ItaliAE Project and the Reorganization of the Italian Administrative Geography}

The main feature characterizing the transition from the eGovernment Laboratory to the logic of Innovation Communities lies in the abandonment of the ICT intervention and in the location of technology at the heart of an ambitious re-planning program of institutional geography of Local Authorities within the framework of European Programming 2014-2020. In this regard, the Department for Regional and Local Affairs in 2017 obtained funding of 13.085.266 € for the National Operational Program "Governance and Institutional Ability" to implement a project called ItaliAE (http://www.pongovernance1420.gov.it/it/progetto/italiae/), within the European Thematic Objective 11 - " Enhancing institutional capacity of public authorities and stakeholders and efficient Public Administration" dedicated to capacity building (Comitato di Pilotaggio OT11-OT2, 2017).

In particular, the ItaliAE project was imagined to sustain the reform of local governments coming from Law n. 56/2014, supporting its implementation through a pervasive capacity action that does not confine ICT to a technological gadget, but instead puts technology at the heart of structure and processes. This design allows to give a new contextualization and it 
allows to implement the aims and the courses of action of the eGovernment Laboratory, already outlined ( $\$ 3.1$ ). We refer here to the last three areas of action, that support the Local Authorities in the implementation of organizational, managerial and technological models aimed at strengthening governance ability, analysing and promoting the dissemination of over-municipal coordinated management models of innovation and, finally, accompanying the consolidation of Metropolitan Cities within a development strategy to improve its programming capacity.

The ItaliaAE project aims to implement an ambitious process of progressive review of the entire territorial administrative geography, shared with all levels of government and with a strong role of local government associations. The project strategy is based on three pillars: the modernization of the territorial administrative system; improving the performance of Public Administrations and enhancing institutions governance ability; the experimentation and dissemination of innovative practices. The project aims to promote the transition from the current 8,000 municipalities to 1,000 territorial communities capable of a real strategic and effective administration, on the model of the German kreise and the French communitée nouvelle, using technology as its first tool, spreading the winning model of the aggregations tested in the ELISA program (Vetritto, 2017). Unfortunately, the very slow starting of the entire National Operational Program "Governance" made it impossible to assure the necessary continuity between the ELISA program and the ItaliAE project. Many local authorities and relevant academic and social stakeholders, involved first in the definition, and then in the programming and budgeting of the complex architecture of ItaliAE, worked for months in a context of indecision and uncertainty.

At the beginning of 2018 an organizational change in the Department for Regional and Local Affairs led to the substitution of the project manager of ItaliAE. In the following months, the results of political elections led to a new Government, that decided further changes in the Department for Regional and Local Affairs and, most of all, a political change of view about inter-municipal cooperation and redesign of administrative geography of Italy.

As a consequence, ItaliAE is still at the starting blocks and didn't produce any significant result in the direction described above until today. It's impossible to imagine if the policy design underlined in ItaliAE will have any implementation; the legislative proposals that are discussed in these days, anyway, open the path to a revenge of the traditional fragmentation and incommunicability among local authorities, and even to the revival of Napoleonic Provinces. In this case, ItaliAE will be dead before being born.

\section{Conclusions}

In September 2016, within the Presidency of the Council of Ministers, the Italian Government has set up a Team for the Digital Innovation (http://teamdigitale.governo.it), Team hereafter, in order to make technological services more available and efficient to citizens and businesses, to boost innovative digital products and support Public Administrations, at any level, when taking any kind of decisions by using big data and machine learning. Among its various tasks, the Team has to detect new initiatives regarding digital and technical innovations; become an authoritative centre for digital and innovation competences for public stakeholders in order to share guidelines, directives and opinions; create an international community of developers and designers able to help in the development of API and digital services, detect and solve the technological problems and give information and instructions on digital innovation, and lastly, create shared instruments and services, lay the groundwork for an evolving structure able to climb over time and able to keep up with the new technologies that will come up.

In order to fulfil its institutional mission, the Team must also coordinate the various public stakeholders in the management of existing digital and future programmes, in an integrated manner, through a flexible methodology and an open data approach. The Team must also enhance the positive experiences already existing in Public Administration. AGID and the Team represent nowadays the institutions leading the technological and digital revolution within the Public Administration and, to this end, they drew up the three-year plan for information technology in Public Administration, Piano triennale per l'informatica nella Pubblica Amministrazione (AGID, 2019). This constantly evolving programme lays down the operational guidelines for the development of public information technology, the strategic model for the evolutions of the IT systems in Public Administration, the ICT investments coming from public sector in accordance with the EU guidelines.

Up to now and despite repeated reminders, the chain of command of innovation technology has not taken into consideration yet Department for Regional and Local Affairs' job since the ELISA program nor the actual promotion and development of the Innovation Communities.

This cannot be a matter of indifference considering the particular morphological and institutional situation of the Italian fragmented local government system (see § 1.4) where the continuing efforts of recent years to gain efficiency through a more significant aggregation of the local authorities and their functions, also encouraged by the Law n. 56/2016 and inspired by the example of effective reforms in countries like Germany, Poland, Spain and lately France, are far from producing the expected results. 
The recent economic crisis produced on this highly fragmented universe a very negative impact. The aggregated contribution of regions, provinces and municipalities to the internal financial stability mechanism imposed to public budget by the European Commission raised by ten in eight years; the interdiction of turnover of public employees in these administrations is enforced from almost twenty years and has produced an unbearable skills shortage in the offices (especially in the field of technical functions); in many municipalities a lot of fundamental services are practically uncovered. It is definitely deceptive to imagine that in these conditions Italian local authorities could modernize to technological satisfactory standards their services.

This is even more true for the internal areas of the country, once more correctly called shrinking rural region according to ESPON (2017): a very depressed and weak set of areas, affected by depopulation, where anyway still lives almost $23 \%$ of the Italian citizens, according to the date presented by the Italian agency for the territorial cohesion, Agenzia per la Coesione Territoriale (2014), regarding the national strategy for inner areas.

In spite of these evidences, there are no adequate improvements in the fulfilment of a comprehensive reform of local authorities, thus many reforming laws have been passed since the Law n. 142/1990, and until the recent Law n. 56/2014, almost entirely still written on the sand (Vetritto, 2016). This block depends on many factors, not last the lack of awareness and interest of administrative authorities responsible for ICT in the public sector. These authorities seem to dream of an Italy composed only by advanced cities, that doesn't exist; every plan referred to the deployment of technology in the small, peripheral and minor municipalities is conceived to minimize efforts and burdens.

Quite the opposite, new generation technology is an incredible chance to help at last citizens of the more disadvantaged areas to reach the same quality levels of life run by people living in cities. Their "second Italy" is not "minor" than the more reputed and richer Italy of the well-known cities.

Only an effective digital agenda can move citizens of these areas to benefit from the same level of public services and functions already available in the metropolitan areas, through telemedicine to tele-assistance, from video surveillance to energy saving technologies, to dematerialization of administrative procedures and acts.

It is unfair to the constitution, politically suicide and too costly on the administrative level to go on imagining that such a high number of Italian citizens could be excluded from the deployment of many interesting and effective national ICT services, that still can't reach the administrative core of this disadvantaged municipalities.

Yet, from what has been said here, we can figure out what are the challenges we have to face during implementation. The lack of funds could mine the implementation of the programmes; we could not be able to coordinate the Local Authorities' job with the Central Administration, or a change in government and/or policy orientation could curb or even stop the whole innovation process. In particular, the management of relationships between Central Administration and Local Authorities is a flagship of the ELISA program, because it avoided imposing generic solutions from above and didn't exclude territories from decision making. Department for Regional and Local Affairs' project to devise an innovation program for the Public Administration, supported and stimulated by regulatory actions and public funding, and also prioritise local free enterprise and innovation capacity by entrusting them with design qualities, is still stuck.

What we can learn from the ELISA program is how to deal with simplification and innovation projects to be implemented at local level. These data emerged as output of the first action of the e-Government Laboratory $(\S 2.3)$ and they highlight the fact that it is not enough to define the objectives, there shall be also a continuous programme for implementation and control of the results; for example, entrusting the local authorities with solutions is a real critical step which need to be monitored closely. It is important to ensure that local authorities are able to co-ordinate actions, both during the design phase and at a later stage, acknowledging that, as we have seen, different communities of different size and with different policies and levels have trouble in cooperating. Best results can be achieved when the project has its impacts on the provincial or regional authority that co-financed the process or on the area concerned. They also have better results when private companies are not a simple service and product provider, but become real partners in the project: in this context the collaboration is positive since the private consider the project and its results as a chance of growth for its own business area. Lastly, increasing the innovation level of projects will be more efficient to develop ad hoc solutions instead of modify the ones already existing whereas the consolidation of the networking mechanisms built during the design phase will become eligible assets to new funding in order to develop new projects.

The ItaliAE project and the dynamic heritage of the ELISA program were to go on their own way, in the terms described here, assuming that, in a complex administrative system, it's important to provide a concept competition, believing that the best practice will emerge as such. Anyway, after almost 20 years since the first Action Plan on eGovernment in 2001 and a quarter of a century since the creation of the former national authority for computerisation in Public Administration, Autorità Informatica per la Pubblica Amministrazione (AIPA), whereof AGID is the heir, we still do the same mistakes to approach the technological innovation process as a "vertical" topic instead of seeing it as the government main instrument of horizontal mainstreaming. Even from the general methodological point of view the betrayal of ItaliAE project would be 
a further defeat in the cultural challenge to all the limits of the Italian administrative system.

\section{References}

Agenzia per la coesione territoriale. (2014). A strategy for Inner Areas in Italy: definition, objectives, tools and governance. In Materiali Uval Series, 31. Retrieved from http://old2018.agenziacoesione.gov.it/opencms/export/sites/dps/it/documentazione/servizi/materiali_uval/Documen ti/MUVAL_31_Aree_interne_ENG.pdf

AGID. (2014). The Italian strategy for next generation access network. Retrieved from https://www.agid.gov.it/sites/default/files/repository_files/documentazione/next_generation_access_network_-_eng lish_version.pdf

AGID. (2016). Strategia per la crescita digitale 2014-2020. Retrieved from https://www.agid.gov.it/sites/default/files/repository_files/documentazione/strategia_crescita_digitale_ver_def_210 62016.pdf

AGID. (2019). Piano triennale per l'informatica nella pubblica amministrazione 2019-2021. Retrieved from https://pianotriennale-ict.italia.it/assets/pdf/2019-2021/Piano-Triennale-ICT-2019-2021.pdf

Barca, F. (2011). Alternative approaches to development policies: intersections and divergences. In OECD Regional Outlook 2011 (pp. 215-225). Paris, France: OECD. https://doi.org/10.1787/9789264120983-17-en

Bobbio, N. (1974). La grande dicotomia. In Studi in memoria di Carlo Esposito (pp. 2187-2200). Padova, Italy: CEDAM.

Castells, M. (2010). The rise of the network society. The information age ( $2^{\text {nd }}$ ed.). In Blackwell Publishers (ed.), Economy, Society and Culture, 1. Oxford, England: Wiley Blackwell. https://doi.org/10.1002/9781444319514

Christensen, T., \& Laegreid P. (2006). Agencification and the regulatory reform. In T. Christensen, \& P. Laegreid (Eds.), Autonomy and regulation: coping with agencies in the modern state. (pp.8-49). Cheltenham, England: Edward Elgar.

Comitato di Pilotaggio OT11-OT2. (2017). The monitoring of the implementation of thematic Objectives 11 and 2 in Italian National and Regional ESIF Operational Programmes. Retrieved from http://www.ot11ot2.it/sites/default/files/ex_sum_monitor-ot11ot2-eng.pdf

Dahrendorf, R. (1959). Class and class conflict in industrial society, Stanford, CA: Stanford University Press.

Dahrendorf, R. (2003). Libertà attiva. Sei lezioni su un mondo instabile, Bari, Italy: Laterza.

Department for Regional and Local Affairs \& Politecnico di Milano - School of Management. (2014). Reti di Città Intelligenti. Risultati e prospettive Programma ELISA. Milano, Italy: Politecnico di Milano, 2014. Retrieved from http://www.affariregionali.it/media/169091/labegov.pdf

Dunleavy P., Margetts H., Bastow, S. \& Tinkler, J. (2005). New public management is dead-long live digital-era governance. Journal of Public Administration Research and Theory, 16(3), 467-494. https://doi.org/10.1093/jopart/mui057

ESPON. (2017). Policy brief on shrinking rural regions in Europe. Luxembourg: ESPON. Retrieved from https://www.espon.eu/sites/default/files/attachments/ESPON\%20Policy\%20Brief\%20on\%20Shrinking\%20Rural\% 20Regions.pdf

European Commission. (2017). Europe's digital progress report (EDPR) 2017. Country profile Italy. European Commission. Retrieved from http://ec.europa.eu/newsroom/document.cfm?doc_id=44314

European Commission. (2018). Digital economy and society index (DESI) 2018. Country profile Italy. European Commission. Retrived from http://ec.europa.eu/newsroom/dae/document.cfm?doc_id=52226

Guy Peters, B., \& Pierre, J. (1998). Governance without government? Rethinking Public Administration. Journal of Public Administration research and theory, 8(2), 223-243. https://doi.org/10.1093/oxfordjournals.jpart.a024379

Hayek, F. A. (1982). Law, Legislation and Liberty: A New Statement of the Liberal Principles of Justice and Political Economy. London, UK: Routledge. https://doi.org/10.1017/S0031819100050877

Hidalgo, C. A., Klinger, B., Barabàsi A., Hausmann L. (2007). The Product Space Conditions the Development of Nations in Science, 317, 482-487. https://doi.org/10.1126/science.1144581

Hirschman, A. O. (1958). The strategy of economic development. New Haven, CT: Yale University Press https://doi.org/10.1177/000271625932500118

Hirschman, A. O. (1963). Journeys towards progress. New York, NY: The Twentieth Century Fund.

Hirschman, A. O. (1967). Development projects observed, Washington, DC: The Brookings Institution. 
Marks, G. (1993). Structural policy and multilevel governance in the EC. In A. Cafruny \& G. Rosenthal (Eds.), The state of the European Community, Vol 2 The Maastricht debate and beyond, (pp. 391-410). Boulder, CO: Lynne Rienner.

OECD. (2005). Modernizing Government. The way forward. Paris, France: OECD Publications. https://doi.org/10.1787/9789264010505-en

OECD. (2017). Multilevel governance reforms: overview of OECD countries experiences. Paris, France: OECD Publications. https://doi.org/10.1787/9789264272866-en

Osborne, D., \& Gaebler, T. (1992). Reinventing government: How the entrepreneurial spirit is transforming the public sector. New York, NY: Addison Wesley. https://doi.org/10.1002/pam.4050130113

Ostrom, E. (1990). Governing the commons. The evolution of institution for collective action. Cambridge, UK: Cambridge University Press. https://doi.org/10.2307/3146384

Perulli, P. (2004). Piani strategici. Governare le città europee. Milano, Italy: Franco Angeli.

Polanyi, K. (2013). Per un nuovo occidente. Scritti 1919- 1958, Milano, Italy: il Saggiatore.

Pollitt, C., \& Bouckaert, G. (2004). Public management reform: A comparative analysis (2 $2^{\text {nd }}$ ed.). New York, NY: Oxford University Press.

Rennie, R. (2005). Sostenere l'innovazione nelle pubbliche amministrazioni. Queste Istituzioni, 136/137, 101-115. Roma, Italy: QUES.I.RE.

Verhoest, K., (2017). Agencification in Europe. In E. Ongaro, \& S. van Thiel (Eds.), The Palgrave Handbook of Public Administration and Management in Europe, (pp. 327-346). Basingstok, UK: Palgrave Macmillan. https://doi.org/10.1057/978-1-137-55269-3

Vetritto, G. (2010). Di cosa parliamo quando parliamo di pubblica amministrazione. Queste Istituzioni. 156/157, 7-16. Roma, Italy: QUES.I.RE.

Vetritto, G. (2016). L'Italia da rammendare. Legge Delrio e ridisegno del sistema delle autonomie. Rivista giuridica del Mezzogiorno, 1, 153-171. https://doi.org/10.1444/83297

Vetritto, G. (2017, June 22). Community d'innovazione, il modello pubblico che sta cambiando il territorio. In Agendadigitale.eu. Retrieved from:

https://www.agendadigitale.eu/cittadinanza-digitale/governare-la-complessita-facendo-sistema-le-community-dinn ovazione/

Von Mises, L. (1933). Grundprobleme der nationalökonomie: untersuchnungen über verfahren; aufgaben und inhalt der wirtschafts- und gesell schaftslehre. Jena, Germany: Gustav Fischer.

World Economic Forum. (2017). Global competitiveness report 2017-2018. Geneva, Switzerland: World Economic Forum. Retrieved from http://www3.weforum.org/docs/GCR2017-2018/05FullReport/TheGlobalCompetitivenessReport2017\%E2\%80\%9 32018.pdf

\section{Copyrights}

Copyright for this article is retained by the author(s), with first publication rights granted to the journal.

This is an open-access article distributed under the terms and conditions of the Creative Commons Attribution license which permits unrestricted use, distribution, and reproduction in any medium, provided the original work is properly cited. 